\title{
Enhanced Expression of Heat Shock Protein 70 (hsp70) and Heat Shock Factor 1 (HSF1) Activation in Rheumatoid Arthritis Synovial Tissue

\author{
Differential Regulation of hsp70 Expression and HSF1 Activation in Synovial Fibroblasts by
} \\ Proinflammatory Cytokines, Shear Stress, and Antiinflammatory Drugs
}

\author{
Georg Schett, ${ }^{\star}$ Kurt Redlich, ${ }^{*}$ Qingbo Xu, ${ }^{\ddagger}$ Peter Bizan,§ Marion Gröger," Makiyeh Tohidast-Akrad," Hans Kiener, \\ Josef Smolen, ${ }^{*}$ and Günter Steiner* \\ *Division of Rheumatology, Department of Internal Medicine III, University of Vienna, Vienna, Austria; ${ }^{\ddagger}$ Institute for Biomedical Aging \\ Research, Austrian Academy of Sciences, Innsbruck, Austria; and ${ }^{\S}$ Clinic of Orthopedics and ${ }^{\|}$Department of Immunodermatology, \\ University of Vienna, "Ludwig Boltzmann-Institute for Rheumatology and Balneology, Vienna, Austria
}

\begin{abstract}
Heat shock proteins (hsp) have been repeatedly implicated to participate in the pathogenesis of rheumatoid arthritis (RA). Herein, we investigated the regulation of synovial hsp70 expression by analyzing the DNA-binding activity of heat shock transcription factor 1 (HSF1) as well as inducible hsp70 expression. Experiments were performed both on synovial tissue and on synovial fibroblast-like cells (SFC). Gel mobility shift analysis revealed increased HSF1 activation, and Western blotting and immunohistochemistry revealed increased hsp70 expression in RA synovial tissue, but not in synovial tissue derived from patients with osteoarthritis. Proinflammatory cytokines (TNF- $\alpha$, IL-1 $\alpha$, IL-6), but not IFN- $\gamma$ or TGF- $\beta$, induced activation of HSF1-DNA binding and hsp70 expression in cultivated SFC. Activation of HSF1 in SFC was accompanied by hyperphosphorylation and nuclear translocation of HSF1. Furthermore, shear stress also induced a complete heat shock response in cultivated synovial cells. In contrast, nonsteroidal antiinflammatory drugs triggered only an incomplete heat shock response, with HSF1 activation but not hsp70 induction, whereas steroids and immunosuppressive drugs did not affect the heat shock response at all. In summary, these data suggest that induction of hsp70 expression in rheumatoid synovial tissue is based on transcriptional activation of HSF1 due to the presence of proinflammatory cytokines (and possibly also shear stress). (J. Clin. Invest. 1998. 102: 302-311.) Key words: stress proteins • fibroblasts • synovial cells $\bullet$ arthritis $\bullet$ tumor necrosis factor- $\alpha$
\end{abstract}

\section{Introduction}

Stress or heat shock proteins (hsp) ${ }^{1}$ are part of a tightly regulated and phylogenetically old biological system that enables organisms to respond adequately to detrimental environmen-

Address correspondence to Dr. Günter Steiner, Division of Rheumatology, Department of Internal Medicine III, University of Vienna, Währinger Gürtel 18-20, A-1090 Vienna, Austria. Phone: 431-404002121; FAX: 431-40400-4306; E-mail: Guenter.Steiner@akh-wien.ac.at

Received for publication 10 December 1997 and accepted in revised form 21 May 1998.

J. Clin. Invest.

(C) The American Society for Clinical Investigation, Inc. 0021-9738/98/07/0302/10 \$2.00

Volume 102, Number 2, July 1998, 302-311

http://www.jci.org tal factors. Based on high interspecies sequence homologies, inducible tissue expression and a strong immunogenicity, hsp have been repeatedly incriminated to be involved in various autoimmune conditions, including RA (1-3). Several multimember families of hsp, characterized by the molecular weight of the proteins encoded, have been described (hsp90, hsp70, hsp60 and small hsp families). Among them, the hsp70 subfamily is one of the most widely studied in mammalian cells. As a chaperone, hsp70 orchestrates and protects the folding of nascent proteins, the refolding of denatured proteins, and the solubilization of protein aggregates under both normal and stressed conditions (4-6). Whereas expression of one of the hsp70 isoforms is constitutive (hsp73), expression of the hsp72 isoform is induced by cellular stress factors. In light of this inducible expression, intensive studies on the regulation of the hsp70 response to a variety of different stimuli have been performed.

hsp expression is mainly regulated at the transcriptional level via activation of one or more heat shock transcription factors (HSF) that bind to DNA at a specific site of the hsp gene promoter region, called the heat shock element (HSE) $(7,8)$. In the cytoplasm, HSFs are constitutively present in a non-DNA-binding state. Their activation is induced by various stresses and leads to hyperphosphorylation entailing oligomerization of HSF to a trimeric DNA binding form and subsequent transport to the cell nucleus (9-11). Two functionally different HSFs are known and the signals leading to their activation appear to be different $(12,13)$. HSF1 has been shown to respond to stress factors such as elevated temperature, cytokines, heavy metal ions, and shear stress (9). On the other hand, HSF2 has been implicated in hsp expression during hemin-induced differentiation of human erythroleukemia cells (14).

The synovial tissue of patients with RA is characterized by a chronic inflammatory process leading to an alteration of cellular homeostasis and finally to severe tissue damage. A variety of different stressors is present in the inflamed synovial tissue of RA patients, each of which has the potential to induce a stress response (15-17). Thus, a multitude of proinflammatory cytokines is produced, among which TNF- $\alpha$ and IL- 1 are the best studied ones and have been shown to play a pivotal role in the inflammatory and destructive process of RA $(18,19)$. The continuous presence of proinflammatory cytokines but also the antiinflammatory drugs applied to virtually all RA patients lead to abnormal conditions for human synovial cells and

1. Abbreviations used in this paper: HSE, heat shock element; HSF, heat shock factor; hsp, heat shock protein(s); NSAID, nonsteroidal antiinflammatory drug; OA, osteoarthritis; SFC, synovial fibroblastlike cells. 
therefore may induce hsp expression. In addition, synovial cells, like endothelial cells, are uniquely exposed to high intensities of mechanical stress, especially shear stress, caused by permanent joint motion and resulting synovial fluid perturbation. Under certain circumstances, such as increased exercise, mechanical stress may exert profound effects on synovial cell metabolism, as demonstrated for endothelial cells in case of hypertension (20).

This study addressed the following questions: $(a)$ is expression of hsp70 induced in synovial tissue of RA patients; $(b)$ how is synovial hsp70 expression regulated at the transcriptional level; and (c) do cytokines, shear stress, and antiinflammatory drugs, as potential synovial stress factors, influence transcriptional regulation and protein expression of hsp70 in synovial fibroblast-like cells (SFC)?

\section{Methods}

Cell culture and treatment. SFC were isolated by enzymatic digestion of synovectomy-derived tissue samples according to a previously described technique (21). Cells were grown in RPMI supplemented with $20 \%$ FCS, L-glutamine, penicillin $(100 \mathrm{U} / \mathrm{ml})$, and streptomycin $(100$ $\mu \mathrm{g} / \mathrm{ml}$ ) in a humidified atmosphere of $95 \%$ air and $5 \% \mathrm{CO}_{2}$. Cytokines (TNF- $\alpha$, IL- $1 \alpha$, IFN- $\gamma$, TGF- $\beta$, and IL-6; all from Boehringer Mannheim, Mannheim, Germany) and antiinflammatory or immunosuppressive drugs (nonsteroidal antiinflammatory drugs [NSAIDs], dexamethasone, cyclosporin $\mathrm{A}$, and methotrexate) were added to the cultures. After incubation for various periods of time at $37^{\circ} \mathrm{C}$, cells were harvested for nuclear and total cell protein preparation. Shear stress was applied by a cone and plate flow apparatus for the exposure of cultured cell layers to defined fluid shear stresses. Details of the shear stress technique and of the components of the apparatus have been described earlier (22). Analyses of total synovial tissue included specimens of three patients with RA, diagnosed according to the 1987 revised criteria of the American College of Rheumatology (23), as well as three patients with osteoarthritis (OA) and two patients with aseptic bone necrosis, as controls.

Protein extraction and Western blot analysis. SFC were incubated with cytokines or antiinflammatory drugs at $37^{\circ} \mathrm{C}$ for $8 \mathrm{~h}$, as indicated in the figure legends. Shear stress $\left(20 \mathrm{dyn} / \mathrm{cm}^{2}\right)$ or heat stress $\left(42^{\circ} \mathrm{C}\right)$ was applied for $30 \mathrm{~min}$ followed by $8 \mathrm{~h}$ of recovery at $37^{\circ} \mathrm{C}$. The cells were washed and harvested on ice in buffer containing $20 \mathrm{mM}$ Hepes (pH 7.5), $0.4 \mathrm{M} \mathrm{NaCl}, 10 \%$ glycerol, $1.5 \mathrm{mM} \mathrm{MgCl}_{2}, 0.2 \mathrm{mM}$ EDTA, $1 \mathrm{mM}$ DDT, $1 \mathrm{mM}$ Pefablock SC (Boehringer Mannheim), $1 \mu \mathrm{g} / \mathrm{ml}$ leupeptin, $1 \mu \mathrm{g} / \mathrm{ml}$ aprotinin, and $0.5 \mathrm{mM}$ PMSF. Cellular debris was removed by centrifugation for $30 \mathrm{~min}$ at $13,000 \mathrm{rpm}$. Preparation of whole tissue extracts was performed by mincing liquid nitrogen-frozen synovial membranes in a Polytron homogenizer in the presence of the buffer described above. Tissue debris and fat were removed by centrifugation at $13,000 \mathrm{~g}$.

Synovial cell or tissue extracts were electrophoresed on $10 \%$ SDS-polyacrylamide gels and transferred to nitrocellulose membranes (BA85; Schleicher \& Schuell, Dassel, Germany). hsp70 expression was detected by a monoclonal antibody to human hsp70 (clone W28; StressGen Biotechnologies Corp., Victoria, Canada, reference 24) as described (25), which specifically recognizes the inducible but not the constitutive members of the human hsp70 family. HSF1 expression was investigated using antibodies against mammalian HSF1 (gift from Dr. R.I. Morimoto, Northwestern University, Evanston, IL; 12, 25).

Immunoprecipitation of HSF1 from cell extracts was carried out by addition of $5 \mu \mathrm{g} / \mathrm{ml}$ anti-HSF1 antibody and $10 \%$ (vol/vol) protein A-Sepharose beads. Precipitated HSF1 was then electrophoresed, blotted to nitrocellulose and finally identified by incubating with a biotinylated antiphosphoserine antibody (Sigma Chemical Co., St. Louis, MO).
Gel mobility shift assays. For analysis of HSF1 transcription factor activity, nuclear protein preparations from stimulated and unstimulated SFC were used. Subconfluent (80-90\%) SFC were treated for $3 \mathrm{~h}$ with cytokines (TNF- $\alpha$, IL- $1 \alpha$, IFN- $\gamma$, IL- 6 , TGF- $\beta$ ) or drugs (NSAIDs, dexamethasone, methotrexate, and cyclosporine A) or subjected to shear stress $\left(30 \mathrm{~min}, 2.5 \mathrm{~h}\right.$ recovery) at $37^{\circ} \mathrm{C}$. For heat stress, cells were incubated for $30 \mathrm{~min}$ at $42^{\circ} \mathrm{C}$. Isolation of nuclear proteins, as initially described by Schreiber (25), and gel mobility shift assays were performed according to a previously described protocol (26). Briefly, DNA binding was determined after incubation of $10 \mu \mathrm{g}$ of nuclear protein or $100 \mu \mathrm{g}$ of synovial tissue extracts, respectively, with $10 \mathrm{fmol}$ of a ${ }^{32} \mathrm{P}$-labeled oligonucleotide containing the HSE sequence from the Drosophila hsp70 promoter (5'-GCCTCGAATGTTCGCGAAGTTT-3'). Reaction buffer contained $10 \mathrm{mM}$ Hepes, pH 7.9, 1 mM DTT, 1 mM EDTA, $80 \mathrm{mM} \mathrm{KCl,} \mathrm{4 \%} \mathrm{Ficoll,} \mathrm{and}$ $1 \mu \mathrm{g}$ poly(dIdC) (Pharmacia Biotechnology, Uppsala, Sweden) as a nonspecific competitor. Samples were electrophoresed on $4 \%$ polyacrylamide gels in $0.5 \times$ TBE $(1 \times$ TBE: $89 \mathrm{mM}$ Tris, $89 \mathrm{mM}$ boric acid, 20 mM EDTA, pH 8.3) which were subsequently dried and autoradiographed. Super-shift assays were performed using antibodies specific for HSF1 and HSF2 (gifts from Dr. I. Morimoto). The antibodies were added to the probes after initial binding reactions between protein extracts and labeled oligonucleotides had been allowed to occur (see above).

Immunohistochemistry. 4- $\mu \mathrm{m}$ cryosections of synovial membranes derived from patients with RA or OA were fixed in acetone for $10 \mathrm{~min}$ and incubated with anti-hsp70 monoclonal antibodies
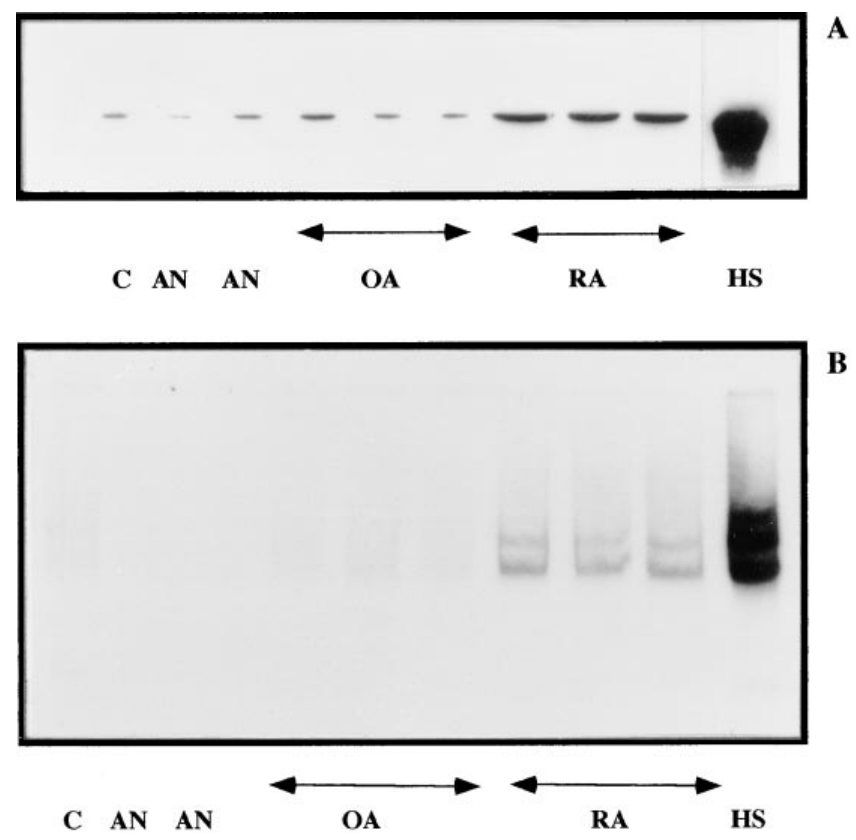

Figure 1. Expression of hsp70 and DNA-binding activity of HSF1 in synovial tissue of OA and RA patients. hsp70 expression and HSF1 activation were investigated by $(A)$ Western blotting and $(B)$ gel mobility shift analysis, respectively, using whole tissue extracts derived from synovial membranes of two patients with aseptic bone necrosis $(A N)$, three patients with OA, and three patients with RA. Nuclear and total proteins of untreated $(C)$ and $42^{\circ} \mathrm{C}$ heat-stressed $(H S)$ synovial cells were used as negative and positive controls, respectively. (A) Western blotting. Extracts (20 $\mu \mathrm{g} / \mathrm{lane})$ were separated on a $12 \%$ SDS gel, blotted onto nitrocellulose membranes, and probed with a monoclonal antibody to hsp70. (B) Gel mobility shift analysis. Extracts $(100 \mu \mathrm{g} / \mathrm{lane})$ were incubated with a ${ }^{32} \mathrm{P}$-labeled probe encompassing a 24-bp HSE of the hsp70 promoter, separated on a $4 \%$ nondenaturing polyacrylamide gel, and autoradiographed. 

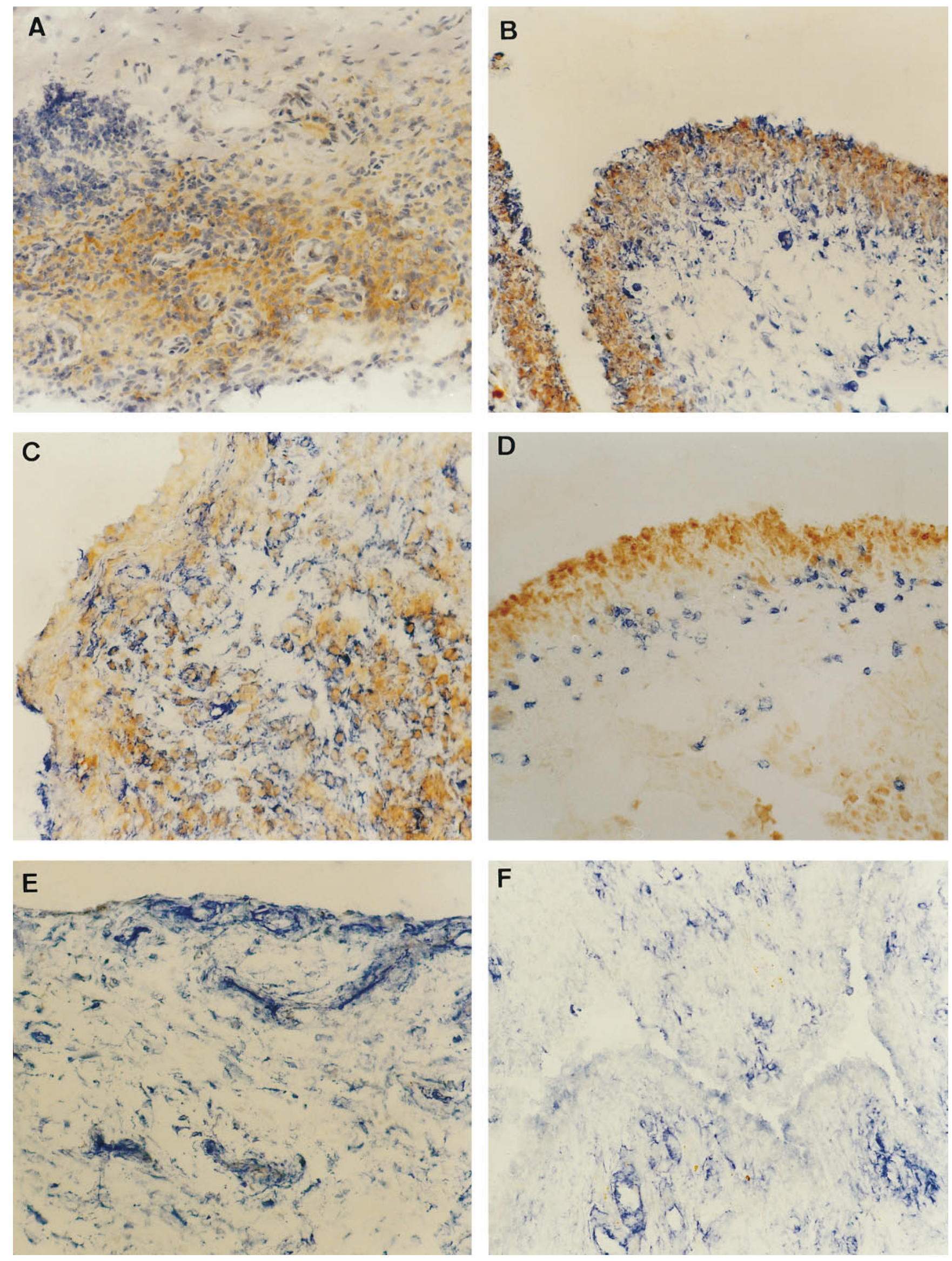

Figure 2. Immunohistochemical analysis of hsp70 expression in RA and OA synovial tissue. Cryosections of synovial tissue from patients with RA $(A-D$ and $F)$ and OA $(E)$ were stained with an anti-hsp70 monoclonal antibody $(A-E)$ or an unrelated control antibody $(F)$. To characterize 

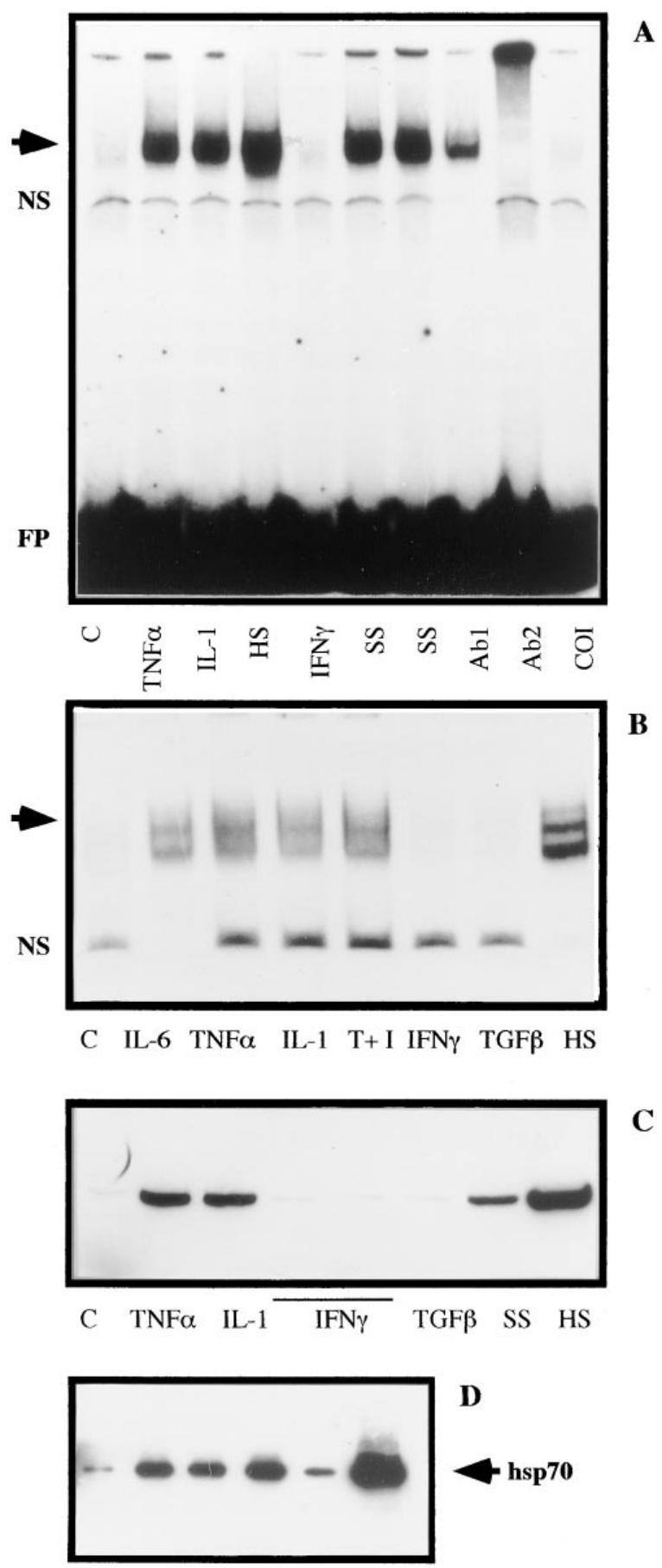

C TNF $\alpha$ IL-1 T+I IL-6 HS

Figure 3. DNA-binding activity of HSF1 and expression of hsp70 in SFC treated with cytokines, shear stress, and heat stress. SFC were either left untreated at $37^{\circ} \mathrm{C}$ (unstressed control, $C$ ) or were treated
(StressGen) for $1 \mathrm{~h}$ at room temperature. Isotype-matched monoclonal antibodies (Dako, Glostrup, Denmark) served as controls. After rinsing, endogenous peroxidase was blocked with $0.3 \%$ hydrogen peroxide in Tris-buffered saline $(10 \mathrm{mM}$ Tris- $\mathrm{HCl}, 140 \mathrm{mM} \mathrm{NaCl}, \mathrm{pH}$ 7.4) for $10 \mathrm{~min}$. This was followed by a 30 -min incubation with biotinylated horse anti-mouse $\mathrm{IgG}$, and the reaction was then detected by incubating with the VECTASTAIN-ABC reagent (Vector, Burlingame, CA) for another $30 \mathrm{~min}$. Color was developed using diaminobenzidine (Sigma Chemical Co.) leading to brown staining. Finally, slides were counterstained with hematoxylin or Mayer's Hämalaun solution (both from Merck, Darmstadt, Germany). Antibodies specific for fibroblasts (clone AS02; Dianova, Hamburg, Germany), macrophages (anti-CD68, clone KP1; Dako), and T cells (anti-CD3; Becton Dickinson, Mountain View, CA) were used to characterize hsp70-expressing cells in double labeling experiments. Thus, sections were incubated with the primary antibody diluted between 1:20 and 1:100 in Tris-buffered saline for $60 \mathrm{~min}$ at room temperature. After rinsing, alkaline phosphatase-labeled, affinity-purified rabbit antimouse immunoglobulins (Dako) were applied as second antibody for $30 \mathrm{~min}$, followed by incubation with the APAAP complex (Dako). Color was developed using Fast Blue (Sigma Chemical Co.) as substrate leading to blue staining of positive cells. Thus, upon light microscopy, hsp70-expressing cells appeared brown or brown/blue.

RNA isolation and Northern blotting. Total RNA was isolated following a standard protocol (27). RNA (10 $\mu \mathrm{g} / \mathrm{lane})$ was electrophoresed on formaldehyde-agarose gels and transferred to a nylon membrane (Gene Screen Plus; DuPont, Boston, MA). Hybridization and autoradiography were performed using a ${ }^{32} \mathrm{P}$-labeled cDNA probe for hsp70 as described (25). $28 \mathrm{~S}$ and $18 \mathrm{~S}$ ribosomal RNA served as internal standards to control for accuracy of loading as well as integrity of RNA.

Immunofluorescence. Immunofluorescence studies were performed as described (28) with slight modifications. Subconfluent SFC in 8-well chamber slides (Nunc, Naperville, IL) were either heat stressed at $42^{\circ} \mathrm{C}$, or treated with TNF- $\alpha(10 \mathrm{ng} / \mathrm{ml})$ or left at $37^{\circ} \mathrm{C}$, respectively. For analysis of HSF1 nuclear translocation, cells were permeabilized and fixed after a 30-min heat stress or a 3-h incubation with TNF- $\alpha$, respectively, for hsp70 detection cells were analyzed after $8 \mathrm{~h}$ of culture. Cells were permeabilized with $4 \%$ paraformaldehyde for $30 \mathrm{~min}$ and fixed with absolute methanol for $5 \mathrm{~min}$. Staining with antibodies to HSF1, hsp70, or CD3 (Dako), as a control, and FITC conjugates (Dako) was then performed. Slides were finally embedded

with TNF- $\alpha$ (10 ng/ml), IL-1 (10 ng/ml), IL-1 + TNF- $\alpha$ (each $5 \mathrm{ng} / \mathrm{ml}$, $T+I), \mathrm{IFN}-\gamma(30 \mathrm{ng} / \mathrm{ml})$, TGF- $\beta(10 \mathrm{ng} / \mathrm{ml}), \mathrm{IL}-6(10 \mathrm{ng} / \mathrm{ml})$, shear stress $\left(10 \mathrm{dyn} / \mathrm{cm}^{2}, 30 \mathrm{~min}, S S\right)$, or heat stress $\left(42^{\circ} \mathrm{C}, H S\right) .(A$ and $B)$ Gel mobility shift assay. SFC nuclear extracts $(10 \mu \mathrm{g} / \mathrm{lane})$ were incubated with radiolabeled HSE oligonucleotide (see Fig. 1). The arrows indicate specific HSF1 binding complexes; $N S$, nonspecific binding; $F P$, free probe. For supershift analysis, an isotype-matched control anti-CD3 antibody ( $A b 1)$ and an anti-human HSF1 antibody ( $A b 2)$ was used. Cold oligonucleotide competition (COI) was performed by addition of a 50-fold excess of nonlabeled HSE oligonucleotide to the HSF1/DNA-binding reaction. ( $C$ and $D$ ) Western blot analysis of hsp70 expression in SFC whole cell extracts ( $25 \mu \mathrm{g} / \mathrm{lane})$.

\section{Figure 2 legend (Continued)}

hsp70-expressing cells, tissues sections were double-stained using antibodies specific for human fibroblasts $(B, E$, and $F)$, macrophages $(C)$, and T cells $(D)$. hsp70-expressing cells appear brown, cell surface markers are stained blue. $(A)$ Synovial tissue from a patient with RA stained with anti-hsp70 antibody and counterstained with hematoxylin. $(B-D)$ Synovial tissue from patients with RA stained with anti-hsp70 and antibodies specific for fibroblasts, macrophages, and T cells. Strong hsp70 staining (brown) can be seen throughout synovial tissue with the synovial lining being the most intensively stained part. hsp70 staining colocalized with synovial fibroblasts $(B)$ and macrophages $(C)$, but not with T cells $(D)$. $(E)$ Synovial tissue from a patient with OA stained with anti-hsp70 and fibroblast-specific antibody. $(F)$ RA synovial tissue stained with control antibody and fibroblast-specific antibodies. Original magnification, $\times 100$. 
in $n$-propylgalate/glycerol (Sigma Chemical Co.) and analyzed by confocal laser scanning microscopy (Carl Zeiss Inc., Jena, Germany).

\section{Results}

hsp70 expression and HSF1 activation in synovial tissue. To assess whether expression of hsp70 is enhanced in RA synovial tissue, Western blotting of whole synovial tissue extracts from RA and OA patients was performed (Fig. $1 A$ ). Upregulation of hsp70 expression was detected only in RA synovial tissue, whereas synovial tissue from $\mathrm{OA}$ or from control patients (aseptic bone necrosis) displayed only baseline expression. The enhanced expression of synovial hsp70 was associated with transcriptional activation of HSF1 in RA which could not be detected in the control samples (Fig. $1 B$ ).

When investigating cryosections of RA synovial tissue by immunohistochemistry, high expression of hsp70 was observed. Strong staining intensities were seen throughout RA synovium with a majority of cells positive for hsp70 (Fig. $2 A$ ). Double staining with markers specific for fibroblasts (Fig. $2 B$ ), macrophages (Fig. $2 C$ ), and T cells (Fig. $2 D$ ) revealed colocalization of hsp70 expression (brown) with fibroblasts and macrophages (blue). hsp70-positive fibroblasts and macrophages were found throughout whole synovial tissue but were most prominent in the synovial linings with almost every cell positively stained, as shown in Fig. $2, B$ and $C$. No colocalization was found with synovial T cells (Fig. $2 D$ ). Compared with RA, only a few cells were found to express hsp70 in OA synovial tissue (Fig. 2 E).

Regulation of hsp70 expression and HSF1 activation by proinflammatory cytokines and shear stress. To analyze the individual factors leading to activation of HSF1 and induction of hsp70, cultivated SFC were incubated with stimuli known to be present in RA synovial tissue and/or having the potential to induce a stress response. Both proinflammatory cytokines, TNF- $\alpha$ and IL-1, induced an hsp70 response, resulting in transcriptional activation of HSF1 (Fig. $3 A$ ) and enhanced hsp70 protein expression (Fig. $3 C$ ). Costimulation by TNF- $\alpha$ and IL-1 had an additive effect on both HSF1 activation (Fig. $3 B$ ) and hsp70 expression (Fig. $3 \mathrm{D}$ ). IL-6, which is also considered a proinflammatory mediator in synovitis, induced HSF1 activation but weaker upregulation of hsp70, whereas both IFN- $\gamma$ and TGF- $\beta$ failed to activate HSF1 and hsp70 expression (Fig. $3, B$ and $D$ ). Shear stress at an intensity similar to arterial blood flow ( $20 \mathrm{dyn} / \mathrm{cm}^{2}, 30 \mathrm{~min}$ ) strongly induced both HSF1 activation and hsp70 expression (Fig. 3, $A$ and $C$ ). Heat stress $\left(42^{\circ} \mathrm{C}\right)$, as positive control $(H S)$, induced maximum response whereas neither HSF1 activation nor hsp70 expression was observed in untreated $\left(37^{\circ} \mathrm{C}\right) \mathrm{SFC}$ which served as negative control $(C)$.

Specificity of HSF1-DNA complexes was confirmed by supershift analysis: addition of anti-HSF1 antibody entailed supershift of HSF1-DNA complexes (Fig. 3, $A$, lane $A b 2$ ), whereas unrelated antibodies (Fig. $3 A$, lane $A b 1$ ) or antibodies to HSF2 (data not shown) had no effect. Furthermore, HSF1 binding to labeled HSE oligonucleotide was blocked by an excess of unlabeled oligonucleotide (Fig. 3, $A$, lane COI).

Activation of HSF1 by TNF- $\alpha$ and IL-1 was dose dependent between 5 and $15 \mathrm{ng} / \mathrm{ml}$ of cytokine added to the cultures (Fig. $4 A$ ). Higher doses did not further enhance HSF1 activation (not shown). Time kinetics revealed maximum DNA binding activity of HSF1 after $3 \mathrm{~h}$ of cytokine incubation (Fig. $4 \mathrm{~B}$ ), which was in accordance with studies performed on smooth muscle cells (29).

Regulation of hsp70 expression and HSF1 activation by antiinflammatory drugs. To investigate the influence of antirheumatic drugs on the hsp70 response, SFC were cultivated in the presence of these drugs, and HSF1 activation as well as hsp70 expression was investigated. NSAIDs induced an incomplete stress response activating HSF1-DNA binding but not hsp70 protein expression (Fig. 5, $A$ and $B$ ). This effect was independent of the type and cyclooxygenase specificity of NSAIDs used. Indomethacin, dexibubrufen, and meloxicam exhibited the same effect when equivalent doses $(30$, 300 , and $10 \mathrm{mM}$, respectively) were used. Corticosteroids in
A

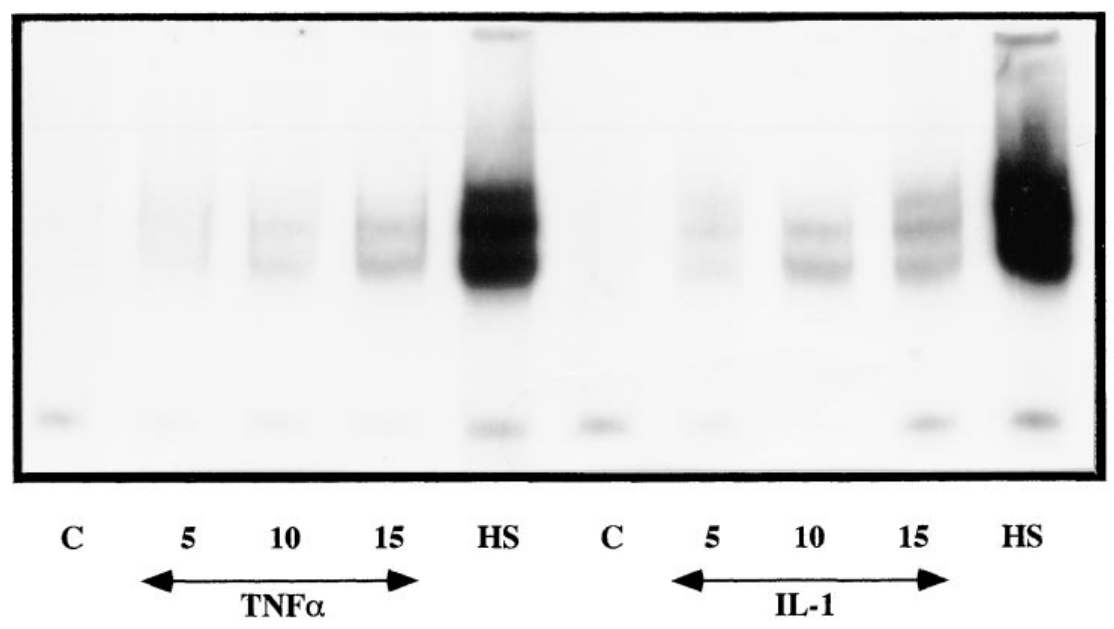

B

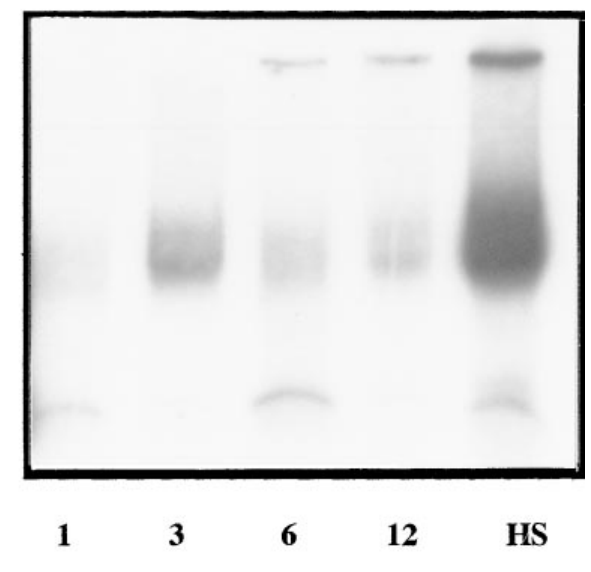

Figure 4. Dose and time response of cytokine-induced activation of HSF1 in SFC. Gel mobility shift analysis of HSF1 binding to radiolabeled HSE oligonucleotide was performed as in Fig. 3. (A) Dose-dependent activation of HSF1 was observed between $5 \mathrm{and} 15 \mathrm{ng} / \mathrm{ml}$ of TNF- $\alpha$ or IL-1 added to the cultures for $3 \mathrm{~h}$. Untreated $(C)$ and $42^{\circ} \mathrm{C}$ heat-stressed $(H S)$ cells served as negative and positive controls, respectively. $(B)$ Time response of HSF1 activation after 1, 3, 6, and $12 \mathrm{~h}$ of incubation with TNF- $\alpha$ (10 ng/ml). Similar kinetics were seen for IL-1 (not shown). 

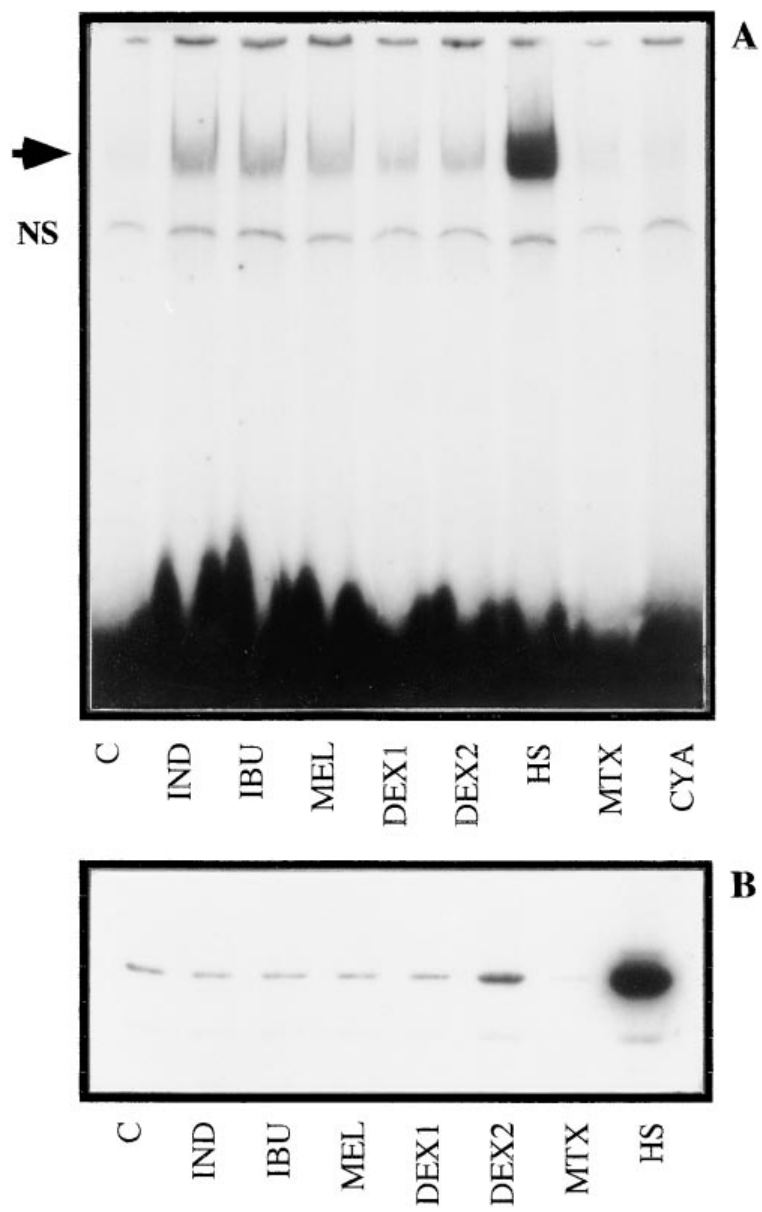

Figure 5. DNA-binding activity of HSF1 and expression of hsp70 in SFC treated with antiinflammatory drugs. SFC were either left untreated at $37^{\circ} \mathrm{C}$ (unstressed control, $C$ ) or were treated with indomethacin $(30 \mathrm{mM}, I N D)$, ibubrufen $(300 \mathrm{mM}, I B U)$, meloxicam (10 $\mathrm{mM}, M E L)$, dexamethasone ( $100 \mathrm{nM}$ to $10 \mathrm{mM}, D E X)$, methotrexate $(100 \mathrm{nM}, M T X)$, and cyclosporine A $(100 \mathrm{nM}, C Y A)$, or heat stress $\left(42^{\circ} \mathrm{C}, H S\right) .(A) \mathrm{Gel}$ shift assays and $(B)$ Western blotting were performed as described in Fig. 3.

moderate to high doses (100 nM to $10 \mathrm{mM}$ ) only weakly increased HSF1 activity which was not encompassed by increased hsp70 protein levels. Only very high doses of glucocorticoids $(100 \mathrm{mM})$ induced a complete stress response. Both immunosuppressive agents investigated, methotrexate $(100 \mathrm{nM})$ and cyclosporine A $(100 \mathrm{nM})$, did not induce the hsp70 stress response. Furthermore, neither of these agents showed any suppressive effect on heat stress induced HSF1 activation (data not shown).

Activation of HSF1 DNA binding but lack of transcriptional activation of the hsp70 gene by NSAIDs was due to incomplete phosphorylation of HSF1 (17), as shown by immunoblotting (Fig. $6 \mathrm{~A}$ ) and immunoprecipitation of HSF1 (Fig. $6 B$ ). As with control or IFN- $\gamma$-treated SFC, only the constitutively phosphorylated lower molecular weight isoform of HSF1 could be detected when SFC were treated with NSAIDs. In contrast, TNF- $\alpha$ - and IL-1-treated cells as well as shear and heat-stressed cells showed the formation of the hyperphosphorylated higher molecular weight isoform of HSF1. Moreover, synthesis of hsp70 mRNA was

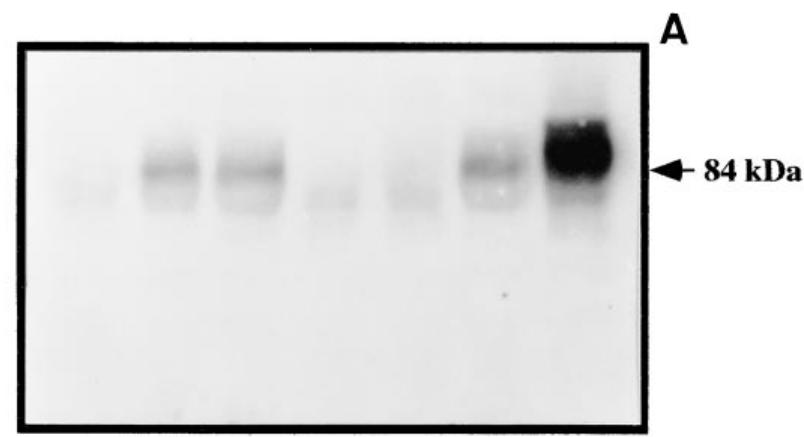

C TNF $\alpha$ IL-1 IFN $\gamma$ IM SS HS

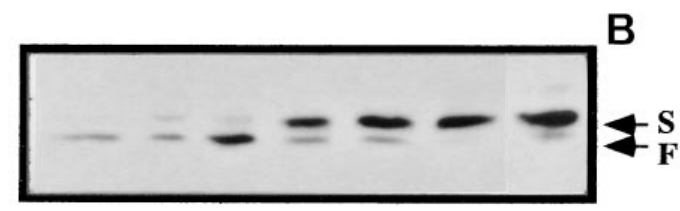

C IFN $\gamma$ IM IL-1 TNF $\alpha$ SS HS

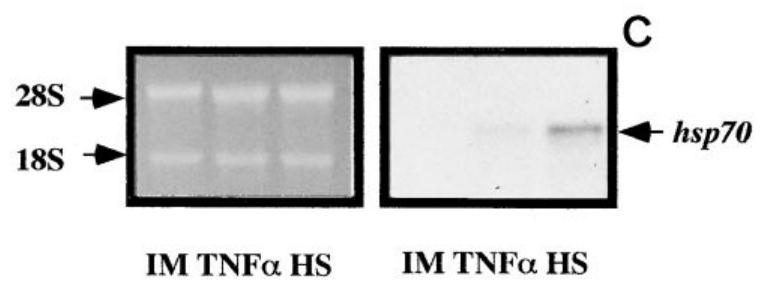

Figure 6. Expression of hyperphosphorylated HSF1 and transcription of hsp70 mRNA. Nuclear protein extracts were prepared from untreated $(C)$, TNF- $\alpha(10 \mathrm{ng} / \mathrm{ml})$, IL-1 $(10 \mathrm{ng} / \mathrm{ml})$, IFN- $\gamma(30 \mathrm{ng} / \mathrm{ml})$, and indomethacin $(I M, 30 \mathrm{mM})$ treated, as well as shear-stressed $(S S)$ and heat-stressed $(H S)$ SFC and analyzed by $(A)$ Western blotting and $(B)$ immunoprecipitation. $(A)$ Western blot analysis. The arrow indicates the position of the slower migrating hyperphosphorylated form of HSF1 showing an apparent molecular mass of $84 \mathrm{kD}$, which can be seen in lanes TNF- $\alpha$, IL-1, SS, and HS. (B) Immunoprecipitation. HSF1 was immunoprecipitated by anti-HSF1 antibody, electrophoresed on a 10\% SDS gel, and analyzed by immunoblotting using an antiphosphoserine monoclonal antibody. The antibody clearly detects the transcriptionally active, hyperphosphorylated form of HSF1 $(S)$ induced by IL-1, TNF- $\alpha$, SS, and HS, but not by IFN- $\gamma$ and indomethacin, as well as the inactive faster migrating isoform $(F)$. $(C)$ Northern blot analysis of hsp70 expression. Total RNA isolated from indomethacin-treated $(I M)$, TNF- $\alpha$-treated, and heat-stressed $(H S)$ SFC was probed with a ${ }^{32} \mathrm{P}$-labeled cDNA specific for hsp70. Induction of hsp70-mRNA synthesis (arrow) was observed in TNF- $\alpha$-treated and heat-stressed, but not in indomethacin-treated, cells.

only induced by TNF- $\alpha$ and heat stress, i.e., in the presence of hyperphosphorylated HSF1, but not by indomethacin (Fig. $6 C$ ).

Immunofluorescence studies. To investigate the expression of hsp70 and HSF1 in heat-stressed and cytokine-treated (TNF- $\alpha$ ) SFC, immunofluorescence studies were performed (Fig. 7). After $42^{\circ} \mathrm{C}$ heat stress (Fig. $7 \mathrm{~A}$ ) or treatment with TNF- $\alpha$ (Fig. 7 B) a marked upregulation of hsp70 was seen, whereas only weak hsp70 expression was observed in untreated SFC (Fig. 7 C). As described for other cells, hsp70 pre- 

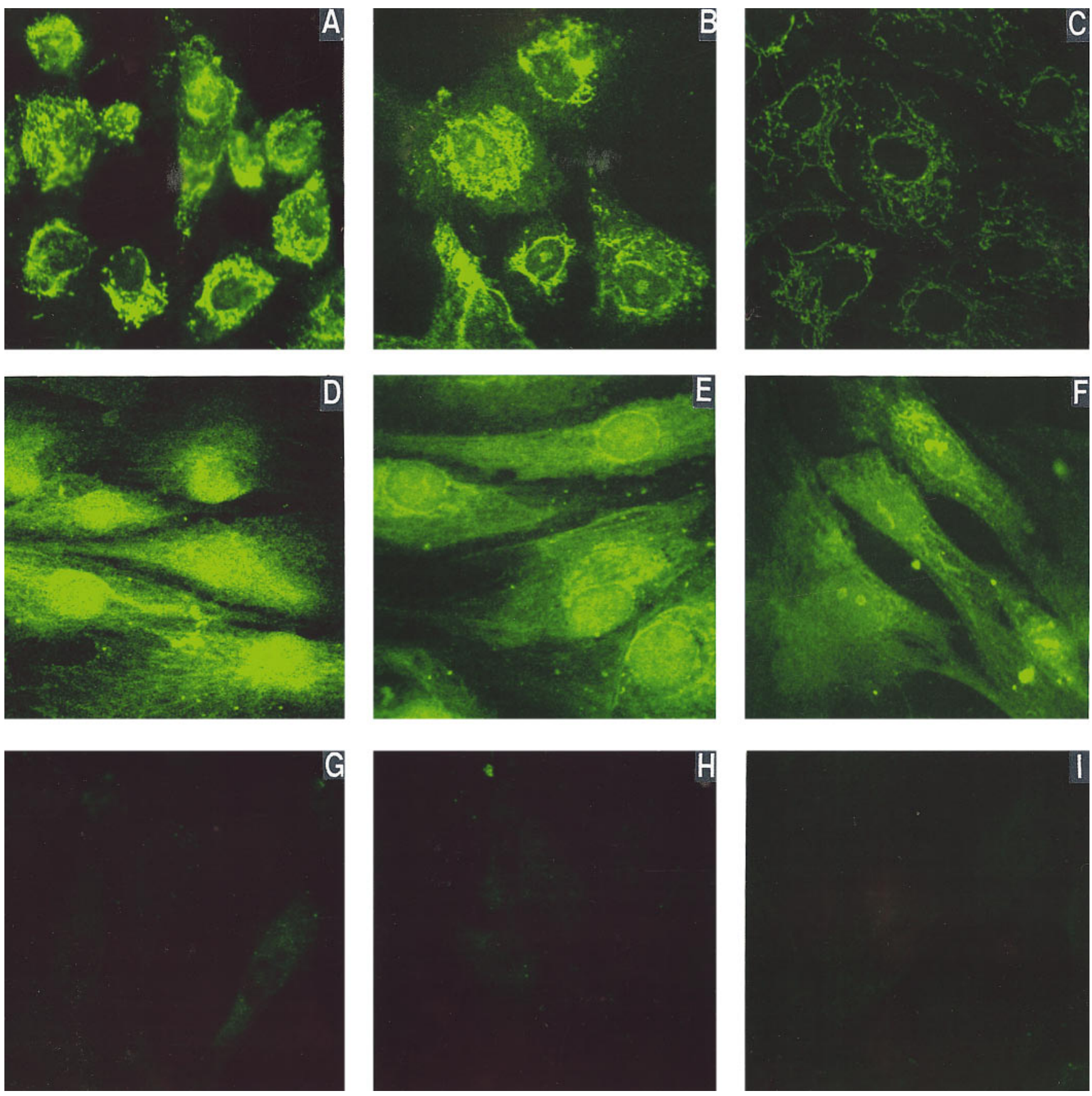

Figure 7. Induction of hsp70 expression and nuclear translocation of HSF1 studied by immunofluorescence microscopy. SFC cultivated in chamber slides were either $42^{\circ} \mathrm{C}$ heat stressed $(A, D$, and $G)$, incubated with TNF- $\alpha(B, E$, and $H)$, or left untreated $(C, F$, and $I)$. Permeabilized and fixed cells were then probed with antibodies to human hsp70 $(A-C)$, HSF1 $(D-F)$, or CD3 $(G-I)$, as a control. Note the inducible expression of hsp70 as well as nuclear translocation of HSF1 induced by heat stress $(A$ and $D)$ or TNF- $\alpha(B$ and $E)$, compared with unstressed cells $(C$ and $F)$. Analysis was performed with a laser scanning microscope at a magnification of 400 .

dominantly localized in the cytoplasm, the most intensive staining being found around the cell nucleus. Both heat and cytokine treatment entailed nuclear translocation of HSF1, resulting in a prominent nuclear staining of SFC (Fig. 7, $D$ and $E)$. In untreated cells, HSF1 was predominantly found in the cytoplasm, indicating the presence of the inactive cytoplasmatic form of HSF1 (Fig. $7 F$ ). In accordance with the data from the experiments described in the previous sections, HSF1 translocation and hsp70 upregulation induced by $\mathrm{TNF}-\alpha$ was weaker compared with heat stress, which induced a maximal response.

\section{Discussion}

RA synovial tissue is characterized by a chronic inflammatory process with mononuclear cell infiltration and proliferation of 
synovial tissue leading to the formation of synovial pannus. The presence of proinflammatory cytokines, antiinflammatory drug therapies, and the fact that synovial tissue is uniquely exposed to high mechanical stress form conditions which potentially induce stress protein synthesis. Herein, we have demonstrated upregulation of hsp70 expression in synovial tissue of patients with RA, but not in patients with OA, indicating effective cellular stress mechanisms ongoing in RA synovial tissue. Induced hsp70 expression was associated with activation of HSF1 transcription factor and enhanced transcription of the hsp70 gene. Proinflammatory cytokines, including TNF- $\alpha$, IL-1, and IL-6, as well as shear stress, were able to induce hsp70 expression presumably via HSF1 activation in synovial cells, whereas antiinflammatory drugs or cytokines such as IFN- $\gamma$ or TGF- $\beta$ did not or only incompletely induce hsp70 activation in SFC.

TNF- $\alpha$ and IL-1 are considered to play an essential part in initiation and perpetuation of synovitis (18). Both cytokines are produced in situ by infiltrating macrophages, and overexpression of both TNF- $\alpha$ and IL-1 (30-32) as well as their receptors (33) has been shown to occur in RA synovial tissue and fluids. TNF- $\alpha$ triggers profound alterations in synovial tissue, such as bone and cartilage resorption, increased adhesion molecule expression, and collagenase synthesis $(31,34,35)$. In addition to its proinflammatory properties, IL-1 is involved in activation of metalloproteinases and inhibits proteoglycan synthesis $(36,37)$. Many of these effects may lead to cell stress and finally even to cell death (by apoptosis) making increased chaperonin function and thus hsp70 expression necessary.

The mechanisms of converting mechanical stress into biochemical signals are of growing interest, since several tissues, i.e., blood vessels, are subjected to high shear forces, influencing the metabolism of the neighboring cells. Hypertension, for example, leads to increased mechanical load onto smooth muscle cells and triggers a number of biochemical changes, including HSF1 activation and hsp70 expression (38). In joints, shear stress triggered by synovial fluid motion may vary greatly dependent on the quantity of joint motion and exercise. In addition, the loss of a smooth synovial surface due to chronic inflammation may give rise to turbulent flow of the synovia and an increased rate of shear stress. Shear stress, at a rate similar to that applied in mechanical stress models of joints (39), induced transcriptional activation of HSF1 and hsp70 expression in synovial cells and thus may contribute to the overexpression of hsp70 observed in RA synovial tissue. Although shear stress activates cytokine transcription factors such as AP-1 and NF$\mathrm{kB}$ (40), the activation of HSF1 and hsp70 seems to be regulated directly, since neosynthesis of cytokines such as TNF- $\alpha$ and IL-1 would require longer time and these cytokines were not detectable in cell culture supernatants derived from shearstressed cells (our unpublished observation).

Due to the presence of multiple antiinflammatory drug therapies, ex vivo analysis of tissue and cells of RA patients may be influenced by the effects of these various drugs. Common signal transduction and transcription factor activation pathways have been demonstrated to be influenced by antiinflammatory drugs (41). NSAIDs have been shown to induce HSF1 activation in human lymphocytes $(42,43)$, yeast (44), and Drosophila (45), but activation was not followed by transcription of the hsp70 gene or enhanced protein expression (42-45). This incomplete heat shock response mediated by NSAIDs was based on incomplete phosphorylation of HSF1, lacking the inducible phosphorylation of a serine residue, in contrast to heat-induced HSF1 (46). Both glucocorticoids and immunosuppressants including cyclosporine A and methotrexate did not affect HSF1 activation, nor hsp70 protein expression. Since these drugs inhibit the production of cytokines including TNF- $\alpha$ and IL-1 (47), these results corroborate the connection of hsp expression with proinflammatory mechanisms rather than with antiinflammatory drugs.

hsp have been shown to protect cells against a broad range of toxic conditions, including oxidative stress, $\mathrm{TNF}-\alpha$, heat shock, heavy metals, and cellular damage after ischemia (48, 49). In addition, hsp70 overexpression has been shown to protect from apoptotic cell death (50) and therefore synovial cells expressing elevated hsp70 levels may develop a certain resistance to apoptosis. This would be in line with the observation of only a relatively low frequency of apoptotic cells in rheumatoid synovium despite the abundance of apoptosis-inducing factors (51).

Due to their inducibility, strong immunogenicity, and high interspecies homologies, hsp have been repeatedly incriminated to participate in autoimmune disease. The arthritogenic role of mycobacterial hsp65 in adjuvant arthritis of rats is well established $(1,3)$, whereas the role of hsp in human RA is seen controversially, although $\mathrm{T}$ cell and antibody autoimmunities against hsp60 have been described in RA (52-54). In adjuvant arthritis the immune reactions against hsp60 have been shown to be protective (55), which is corroborated by recent data from children with juvenile chronic polyarthritis $(56,57)$. Whether hsp70 itself is targeted by the autoimmune response in RA remains to be clarified. Although autoantibodies to the constitutive hsp70 isoform have been described in SLE and mixed connective tissue disease $(58,59)$, such antibodies have also been found in healthy subjects (60). However, no study has been performed on antibodies against inducible hsp70 in RA.

Remarkably, hsp70 has been identified recently as the ligand of a highly homologous amino acid motif in the third hypervariable region of the MHC DR $\beta 1$ chain commonly found in alleles carrying susceptibility to RA (2). It is hypothesized that hsp70 participates in the intracellular trafficking and peptide association of these DR $\beta 1$ chains. Therefore, it could be speculated that an alteration of hsp70 expression induced by stress at least quantitatively influences the immunologic processes in which these motifs are involved. Since hsp70 is critically involved in protein folding and therefore also in MHC-peptide assembly, its overexpression might influence processing and presentation of synovial cell antigens, possibly leading to a quantitatively and qualitatively altered antigenic repertoire in rheumatoid synovia. In addition, hsp70 overexpression may prevent apoptotic cell death, facilitating synovial growth and pannus formation. It remains to be clarified if hsp70 induction is just an indicator of severe alterations in cellular and tissue metabolism in RA tissue or is actively involved in the pathogenesis of this disease.

\section{Acknowledgments}

We thank Dr. R.I. Morimoto, Northwestern University (Evanston, IL), for providing us with the antibodies against HSF1 and HSF2 and C.W. Steiner for excellent technical assistance.

This work was supported in part by grant P-12568-MED (to Q. $\mathrm{Xu}$ ) from the Austrian Science Foundation. 


\section{References}

1. Van Eden, W., and D.B. Young. 1996. Stress Proteins in Medicine. Marcel Dekker, Inc., New York/Basel/Hong Kong.

2. Auger, I., J.M. Escola, J.P. Gorvel, and J. Roudier. 1996. HLA-DR4 and HLA-DR10 motifs that carry susceptibility to rheumatoid arthritis bind 70-kD heat shock proteins. Nat. Med. 2:306-310.

3. Van Eden, W., J.E.R. Thole, and R. van der Zee. 1988. Cloning the mycobacterial epitope recognized by $\mathrm{T}$ lymphocytes in adjuvant arthritis. Nature. 31:171-173.

4. Lindquist, S., and E.A. Craig. 1988. The heat shock proteins. Annu. Rev. Genet. 22:631-677.

5. Morimoto, R.I., A. Tissieres, and C. Georgopoulous. 1990. The stress response, function of the proteins, and perspectives. In Stress Proteins in Biology and Medicine. R.I. Morimoto, A. Tissieres, and C. Georgopoulous, editors. Cold Spring Harbor Laboratory Press, Cold Spring Harbor, NY.

6. Schlesinger, M.J. 1990. Heat shock proteins. J. Biol. Chem. 265:1211112114

7. Lis, J., and C. Wu. 1993. Protein trafficking on the heat shock promoter: parking, stalling, and trucking along. Cell. 74:1-4.

8. Morimoto, R.I. 1993. Cells in stress: transcriptional activation of heat shock genes. Science. 259:1409-1410.

9. Sorger, P.K. 1991. Heat shock factor and the heat shock response. Cell. 65:363-366.

10. Welch, W.J. 1993. Heat shock proteins functioning as molecular chaperones: their roles in normal and stressed cells. Phil. Trans. R. Soc. Lond. 339: 327-333.

11. Kim, D., H. Ouyang, and G.C. Li. 1995. Heat shock protein hsp70 accelerates the recovery of heat shocked mammalian cells through its modulation of heat shock transcription factor HSF1. Proc. Natl. Acad. Sci. USA. 92:2126-2130.

12. Sistonen, L., K.D. Sarge, and R.I. Morimoto. 1994. Human heat shock factor 1 and 2 are differentially activated and can synergistically induce hsp70 gene transcription. Mol. Cell. Biol. 14:2087-2099.

13. Fawcett, T.W., S.L. Sylveste, K.D. Sarge, R.I. Morimoto, and N.J. Holbrook. 1994. Effects of neurohormonal stress and aging on the activation of mammalian heat shock factor 1. J. Biol. Chem. 269:32272-32278.

14. Sistonen, L., K.D. Sarge, K. Abravaya, B. Phillips, and R.I. Morimoto. 1992. Activation of heat shock factor 2 during hemin-induced differentiation of human erythroleukemia cells. Mol. Cell. Biol. 14:2087-2099.

15. Koller, M., T. Hensler, B. Konig, G. Prevost, J. Alouf, and W. Konig. 1993. Induction of heat shock proteins by bacterial toxins, lipid mediators and cytokines in human leukocytes. Int. J. Med. Microbiol. Parasitol. Infect. Dis. 278:365-376.

16. Strandell, E., K. Buschard, J. Saldeen, and N. Welsh. 1995. Interleukin-1 beta induces the expression of hsp70, heme oxygenase and Mn-SOD in FACSpurified rat islet beta-cells, but not in alpha-cells. Immunol. Lett. 48:145-148.

17. Lee, B.S., J. Chen, C. Angelidis, D.A. Jurivich, and R.I. Morimoto. 1995. Pharmacological modulation of heat shock factor 1 by anti-inflammatory drugs results in protection against stress-induced cellular damage. Proc. Natl. Acad. Sci. USA. 92:7207-7211.

18. Brennan, F.M., R.N. Maini, and M. Feldmann. 1992. TNF-alpha: a pivotal role in rheumatoid arthritis? Br. J. Rheumatol. 31:293-298.

19. Arend, W.P., and J.M. Dayer. 1995. Inhibition of the production and effects of interleukin-1 and tumor necrosis factor $\alpha$ in rheumatoid arthritis. $A r$ thritis Rheum. 38:1151-1160.

20. Davies, P.F., and S.C. Tripathi. 1993. Mechanical stress mechanisms and the cell: an endothelial paradigm. Circ. Res. 72:239-245.

21. Alvaro-Gracia, J.M., N.J. Zvaifler, and G.S. Firestein. 1990. Mutual antagonism between interferon-gamma and tumor necrosis factor-alpha on HLA-DR expression, proliferation, collagenase production, and granulocytemacrophage colony stimulating factor production by rheumatoid arthritis synoviocytes. J. Clin. Invest. 90:1790-1798.

22. Nagel, T., M. Resnick, W.J. Atkinson, C.F. Dewey, and M.A. Gimbrone. 1994. Shear stress selectively upregulates intercellular adhesion molecule-1 expression in cultured human vascular endothelial cells. J. Clin. Invest. 94:885-891.

23. Arnett, F.C., S.M. Edsworthy, D.A. Bloch, D.J. McShane, J.F. Fries, N.S. Cooper, L.A. Healey, S.R. Kaplan, M.H. Liang, H.S. Luthra, et al. 1988. The American Rheumatism Association 1987 revised criteria for the classification of rheumatoid arthritis. Arthritis Rheum. 31:315-324.

24. Welch, W.J., and G.P. Suchan. 1986. Cellular and biochemical events in mammalian cells during and after recovery from physiological stress. J. Cell Biol. 103:2035-2052.

25. Schreiber, E., P. Mathias, M.M. Müller, and W. Schaffner. 1989. Rapid detection of octamer binding proteins with "mini-extracts," prepared from a small number of cells. Nucl. Acids Res. 17:6419-6425.

26. Xu, Q., L. Ganju, T.W. Fawcett, and N.J. Holbrook. 1996. Vasopressininduced heat shock protein expression in renal tubular cells. Lab. Invest. 74: $178-187$

27. Chomzcynski, P., and N. Sacchi. 1987. Single-step method of RNA isolation by acid guanidinium thiocyanate-phenol-chloroform extraction. Anal. Biochem. 162:156-159.
28. Schett, G., O. Xu, A. Amberger, R. Van der Zee, H. Recheis, and G. Wick. 1995. Autoantibodies against heat shock protein 60 mediate endothelial cytotoxicity. J. Clin. Invest. 96:2569-2577.

29. Xu, Q., Y. Hu, R. Kleindienst, and G. Wick. 1997. Nitric oxide induces heat-shock protein 70 expression in vascular smooth muscle cells via activation of heat shock factor 1. J. Clin. Invest. 100:1089-1097.

30. Chu, C.Q., M. Field, M. Feldmann, and R.N. Maini. 1991. Localization of tumor necrosis factor $\alpha$ in synovial tissues and the cartilage pannus junction in patients with rheumatoid arthritis. Arthritis Rheum. 34:1125-1132.

31. Tetta, C., G. Camussi, V. Modena, C. DiVittorio, and C. Baglioni. 1990 Tumor necrosis factor in serum and synovial fluid of patients with active and severe rheumatoid arthritis. Ann. Rheum. Dis. 49:665-667.

32. Farahat, M.N., G. Yanni, R. Poston, and G.S. Panayi. 1993. Cytokine expression in synovial membranes of patients with rheumatoid arthritis and osteoarthritis. Ann. Rheum. Dis. 52:870-875.

33. Brennan, F.M., D.L. Gibbons, T. Mitchell, A.P. Cope, R.N. Maini, and M. Feldmann. 1992. Enhanced expression of TNF receptor mRNA and protein in mononuclear cells isolated from rheumatoid arthritis synovial joints. Eur. J. Immunol. 22:1907-1912.

34. Saklatvala, J. 1986. Tumor necrosis factor alpha stimulates resorption and inhibits synthesis of proteoglycan in cartilage. Nature. 322:547-549.

35. Osborn, L., C. Hession, R. Tizard, C. Vasallo, S. Lukowskyj, G. ChiRosso, and R. Lobb. 1989. Direct expression cloning of vascular adhesion molecule 1 , a cytokine induced endothelial protein that binds to lymphocytes. Cell. 59:1203-1211.

36. McDonnel, J., L.A. Hoerrner, M.W. Lark, C. Harper, T. Dey, J. Lobner, G. Eiermann, D. Kazazis, I.I. Singer, and V.L. Moore. 1992. Recombinant human interleukin $1 \beta$-induced increase in levels of proteoglycans, stromelysin and leukocytes in rabbit synovial fluid. Arthritis Rheum. 35:799-805.

37. van de Loo, A.A., and W.B. van den Berg. 1990. Effects of murine recombinant interleukin 1 on synovial joints in mice: measurement of patellar cartilage metabolism and joint inflammation. Ann. Rheum. Dis. 49:238-245.

38. Xu, Q., T.W. Fawcett, R. Udelsmann, and N.J. Holbrook. 1996. Activation of heat shock protein transcription factor 1 in rat aorta in response to high blood pressure. Hypertension. 28:53-57.

39. Gomez, J.E., and G.B. Thurston. 1993. Comparisons of the oscillatory shear viscoelasticity and composition of pathological synovial fluids. Biorheology. 30:409-427.

40. Griendling, K.K., and R.W. Alexander. 1996. Endothelial control of the cardiovascular system: recent advances. FASEB (Fed. Am. Soc. Exp. Biol.) J. 10:283-292.

41. Kopp, E., and S. Gosh. 1994. Inhibition of NF-kappa B by sodium salicylate and aspirin. Science. 265:956-959.

42. Jurivich, D.A., L. Sistonen, R.A. Kroes, and R.I. Morimoto. 1992. Effect of sodium salicylate on the human heat shock response. Science. 255:1243-1245.

43. Jurivich, D.A., C. Pachetti, L. Qiu, and J.F. Welk. 1995. Salicylate triggers heat shock factor differently than heat. J. Biol. Chem. 270:24489-24495.

44. Giardina, C., and J.T. Lis. 1995. Sodium salicylate and yeast heat shock gene transcription. J. Biol. Chem. 270:10369-10372.

45. Winegarden, N.A., K.S. Wong, M. Sopta, and J.T. Westwood. 1996. Sodium salicylate decreases intracellular ATP, induces both heat shock factor binding and chromosomal puffing, but does not induce hsp70 gene transcription in Drosophila. J. Biol. Chem. 271:26971-26980.

46. Cotto, J.J., M. Kline, and R.I. Morimoto. 1996. Activation of heat shock factor 1 DNA binding precedes stress-induced serine phosphorylation. Evidence for a multistep pathway of regulation. J. Biol. Chem. 271:3355-3358.

47. Goldfeld, A.E., E. Tsai, R. Kincaid, P.J. Belshaw, S.L. Schrieber, J.L. Strominger, and A. Rao. 1994. Calcineurin mediates human tumor necrosis factor alpha gene induction in stimulated T and B cells. J. Exp. Med. 180:763-768.

48. Sanchez, Y., J. Taulien, K.A. Borkovich, and S. Lindquist. 1992. Hsp 104 is required for tolerance to many forms of stress. EMBO (Eur. Mol. Biol. Organ.) J. 11:2357-2364

49. Jaattela, M., D. Wissing, P.A. Bauer, and G.C. Li. 1992. Major hea shock protein 70, hsp70, protects tumor cells from tumor necrosis factor cytotoxicity. EMBO (Eur. Mol. Biol. Organ.) J. 11:3507-3512.

50. Samali, A., and T.G. Cotter. 1996. Heat shock proteins increase resistance to apoptosis. Exp. Cell Res. 223:163-170.

51. Sugiyama, M., T. Tsukazaki, A. Yonekura, S. Matsuzaki, S. Yamashita, and K. Iwasaki. 1996. Localization of apoptosis and expression of apoptosis related proteins in the synovium of patients with rheumatoid arthritis. Ann. Rheum. Dis. 55:442-449.

52. Celis, L., C. Vandvyver, P. Geusens, J. Dequeker, J. Raus, and J. Zhang. 1997. Clonal expansion of mycobacterial heat shock protein-reactive T lymphocytes in the synovial fluid and blood of rheumatoid arthritis patients. Arthritis Rheum. 40:510-519.

53. Tsoulfa, G., G.A.W. Rook, J.D.A. van Embden, D.B. Young, A. Mehlert, D. Isenberg, F.C. Hay, and P.M. Lydyard. 1989. Raised serum IgG and IgA antibodies to mycobacterial antigens in rheumatoid arthritis. Ann. Rheum. Dis. 48:118-123.

54. De Graeff-Meeder, E.R., R. van der Zee, G.T. Rijkers, H.J. Schuurman, W. Kuis, J.W.J. Bijlsma, B.J.M. Zegers, and W. van Eden. 1991. Recognition of human $60 \mathrm{kD}$ heat shock protein by mononuclear cells from patients with juve- 
nile chronic polyarthritis. Lancet. 337:1368-1372.

55. Hogervorst, E.J.M., J.P.A. Wagenaar, C.J.P. Boog, R. van der Zee, J.D.A. van Embden, and W. van Eden. 1992. Adjuvant arthritis and immunity to the mycobacterial $65-\mathrm{kD}$ heat shock protein. Int. Immunol. 4:719-727.

56. De Graeff-Meeder, E.R., W. van Eden, G.T. Rijkers, B.J. Prakken, W.

Kuis, M.M. Voorhorst-Ogink, R. van der Zee, H.J. Schuurman, P.J. Helders, and B.J.M. Zegers. 1995. Juvenile chronic arthritis. T cell reactivity to human HSP60 in patients with favorable course of disease. J. Clin. Invest. 95:934-940.

57. Prakken, A.B., W. van Eden, G.T. Rijkers, B.J. Prakken, W. Kuis, M.M. Voorhorst-Ogink, R. van der Zee, H.J. Schuurman, P.J. Helders, and B.J.M. Zegers. 1996. Autoreactivity to human heat shock protein 60 predicts disease remission in oligoarticular juvenile rheumatoid arthritis. Arthritis Rheum. 39: $1826-1832$.

58. Minota, S., B. Cameron, W. Welch, and J. Winfield. 1988. Autoantibodies to the constitutive $73-\mathrm{kD}$ member of the hsp70 family of heat shock proteins in systemic lupus erythematosus. J. Exp. Med. 168:1475-1480.

59. Appelboom, T., M.F. Kahn, and N. Mairesse. 1995. Antibodies to small ribonucleoproteins and to $73-\mathrm{kD}$ heat shock protein: two distinct markers of mixed connective tissue disease. Clin. Exp. Immunol. 100:486-488.

60. Kindas-Mügge, I., G. Steiner, and J. Smolen. 1993. Similar frequency of autoantibodies against $70 \mathrm{kD}$ class heat shock proteins in healthy subjects and systemic lupus erythematosus patients. Clin. Exp. Immunol. 92:46-50. 